Acta Universitatis Wratislaviensis No 3705

PRAWO CCCXX

Wrocław 2016

DOI: $10.19195 / 0524-4544.320 .6$

JOANNA NOWAK

Uniwersytet Wrocławski

\title{
Pojęcie prawa administracyjnego i nauki prawa administracyjnego w koncepcji V.E. Orlando
}

\section{Założenia badawcze — wprowadzenie}

Administracja pojmowana jako „komponent życia społecznego”, , jako „pojęcie, które ma objąć pewne zjawiska z dziedziny faktów społecznych"2, jak pisał F. Longchamps de Bérier, obejmuje ,[...] problemy, które wchodzą daleko poza kwestie sprawności czy też skuteczności działania, a wnikają w żywotne sprawy człowieka i społeczeństwa ${ }^{3}$. Na ogół też w każdym kraju istnieje taka część porządku prawnego, która odnosi się właśnie do administracji publicznej [...] jest to prawo administracyjne w dziś przyjętym sensie”4 Choć dalej „dzieli ono rządy

${ }^{1}$ F. Longchamps de Bérier, O administracji publicznej (Problem poznawczy), [w:] Ksiega pamiątkowa ku czci prof. dra Witolda Świdy, red. J. Fiema, W. Gutekunst, S. Hubert, Warszawa 1969 , s. 355.

${ }^{2}$ F. Longchamps de Bérier, $W$ sprawie pojęcia administracji państwowej i pojęcia prawa administracyjnego, „Zeszyty Naukowe Uniwersytetu Wrocławskiego im. Bolesława Bieruta” 1958, s. 19.

3 Dotyczyć mogą przede wszystkim człowieka: ochrony praw lub wartości np. zaufania czy godności. Szerzej: A. Błaś, Studia z nauki prawa administracyjnego i nauki administracji, Wrocław 1998, s. 88-89; Konstytucje Rzeczypospolitej oraz komentarz do Konstytucji RP z 1997 r., red. J. Boć, Wrocław 1998, s. 67-68; J. Korczak, Pozyskiwanie i umacnianie zaufania do wtadz publicznych przez współadministrowanie, [w:] Sprawiedliwość i zaufanie do władz publicznych $w$ prawie administracyjnym, red. M. Stahl, M. Kasiński, K. Wlaźlak, Warszawa 2015, s. 98-114; idem, Konstytucyjne podstawy struktury i funkcji samorzadu terytorialnego, [w:] Konstytucyjne podstawy funkcjonowania administracji publicznej, Warszawa 2012, s. 183-188 (,System Prawa Administracyjnego", red. R. Hauser, Z. Niewiadomski, A. Wróbel, t. 12).

${ }^{4}$ F. Longchamps de Bérier, Wspótczesne kierunki w nauce prawa administracyjnego na zachodzie Europy, reprint, Wrocław 2001, s. 1. 
nad administracją $[\ldots]$ z prawem powszechnym" ${ }^{5}$, ,[...] jest faktem społecznym — pewna działalność intelektualna w sferze badań i refleksji, która bierze sobie za przedmiot prawo administracyjne i przedmiot ten uprawia, w rozmaity zresztą sposób [...]. Jest to [...] nauka prawa administracyjnego"6. I właśnie ta działalność, a właściwie jej rozwój, stała się przedmiotem komparatystycznych badań profesora $^{7}$. Objęły one także Włochy, które w niniejszych rozważaniach będą stanowiły punkt wyjścia. Podstawowy materiał badawczy niniejszego artykułu stanowić będą badania, jakie przez lata prowadził wielki komparatysta i znawca administratywistyki włoskiej - F. Longchamps de Bérier ${ }^{8}$. Będą nim także podręczniki oraz artykuły, w tym także słynny manifest autorstwa Vittorio E. Orlanda (1860-1952), jak i opracowania wtórne, które analizują jego poglądy. Zatem $\mathrm{z}$ jednej strony będą to prace przeglądowe czy też ukazujące ewolucję nauki włoskiego prawa administracyjnego (dla przykładu wskazać tu można opracowania M.S. Gianniniego ${ }^{9}$, A. Sandulli1 ${ }^{10}$, S. Cassesego ${ }^{11}$ czy pracę zbiorową L. Torchia, E. Chiti, A. Sanduli ${ }^{12}$. Z drugiej strony będą to studia dotyczące tylko V.E. Orlando, czyli m.in. prace L. Rameriego ${ }^{13}$, G. Cianferottiego ${ }^{14}$, S. Cassesego ${ }^{15}$ czy

5 F. Longchamps de Bérier, Problemy pogranicza prawa administracyjnego. Wstępne założenia, „Studia Prawnicze”, 1967, z. 16, s. 3 n. Jak pisze autor: „Obszary, na których prawo administracyjne styka się — mówiąc w tej chwili najogólniej — z innymi dziedzinami prawa, można nazwać pograniczem prawa administracyjnego". Zagadnienie to było kontynuowane przez J. Jeżewskiego w pracy: Administracja pod rządem prawa cywilnego. $Z$ badań prawnoporównawczych nauki prawa administracyjnego, Wrocław 1974; idem, Francuska koncepcja poddania administracji publicznej prawu powszechnemu, „Prawo” Wrocław 1972, t. XXX, s. 91-114 („Acta Universistatis Wratislaviensis" No 169).

${ }^{6}$ F. Longchamps de Bérier, Wspótczesne..., s. 1.

7 Określając cel badawczy dzieła, F. Longchamps de Berier pisał: „Zamiarem moim jest zbadać w sposób porównawczy i przedstawić główne kierunki, które się dziś rysują w nauce prawa administracyjnego w krajach Europy Zachodniej”. Zaś określając pole badań, pisze: „Zadaniem pracy jest zdać sprawę z głównych kierunków w nauce prawa administracyjnego", za: F. Longchamps de Bérier, Wspótczesne..., s. 1-8.

8 Szerzej: J. Jeżewski, Franciszek Longchamps de Bérier (1912-1969), [w:] Pamięci zmartych Profesorów i Docentów Wydziału Prawa, Administracji i Ekonomii Uniwersytetu Wrocławskiego 1945-2010, red. L. Lehmann, M. Maciejewski, Wrocław 2010, s. 184-192.

9 M.S. Giannini, Profili storici della scienza del diritto amministrativo, „Quaderni Fiorentini” 1973, nr 2, s. 179-273.

10 A. Sandulli, Costruire lo Stato: la scienza del diritto amministrativo in Italia (1800-1945), Milano 2010.

11 S. Cassese, Il diritto amministrativo: storia e prospettive, Milano 2010.

12 La scienza del diritto amministrativo nella seconda meta del XX secolo, red. Torchia, E. Chiti, A. Sanduli, Napoli 2008.

13 L. Rameri, Principii di Diritto Amministrativo by V.E. Orlando, „Giornale degli Economisti”, 1891 , t. 3, s. $70-76$.

14 G. Cianferotti, Il pensiero di V.E. Orlando e la giuspubblicistica italiana fra ottocento e novecento, „The American Historical Review”, 87, 1982, nr 1, s. 214-215.

15 S. Cassese, Auf der gefahrenvollen Strasse des öffentlichen Rechts. La ,rivoluzione scientifica" di Vittorio Emanuele Orlando, http://www.irpa.eu/wp-content/uploads/2011/10/auf-dergefahrenvollen-Strasse-des-offentlichen-rechts.pdf (dostęp: 12.12. 2014).

Prawo 320, 2016

(C) for this edition by CNS 
F. Grassi Orsiniego ${ }^{16}$ i innych ${ }^{17}$. Należy też wyraźnie zaznaczyć, iż celem, jaki stawia sobie autorka niniejszej publikacji, jest nie tyle dokonanie własnej interpretacji poglądów V.E. Orlanda, ile jak najbardziej rzetelne ich przedstawienie i przybliżenie polskiemu czytelnikowi. Tym samym w dużej mierze artykuł ten także obejmować będzie thumaczenia fragmentów badanych dzieł, które zasługują na przytoczenie, a przede wszystkim będzie to także przypomnienie badań prowadzonych nad włoską administratywistyką, kierowanych przez profesora $\mathrm{F}$. Longchamps de Bériera. Niniejszy artykuł obejmować będzie ustalenia wstępne, które już częściowo podjęto, następnie zaś wskazane zostaną trzy zagadnienia: ustalenie przyczyn, jakie warunkowały badanie i podejście V.E. Orlanda, ustalenie głównych założeń jego manifestu, a także ukazanie w świetle jednego z głównych podręczników tegoż autora - Principi di diritto amministrativo - treści, jakie składają się na naukę prawa administracyjnego i samego prawa administracyjnego. Ponadto w nawiązaniu do badań F. Longchamps de Bériera podkreślony zostanie wpływ doktryny niemieckiej.

\section{Uwarunkowania historyczno-społeczne poglądów V.E. Orlanda}

Już na wstępie należy zaznaczyć, iż lata życia Vittorio Emanuele Orlanda przypadają na okres, w którym „włoska myśl prawna weszła w krąg wpływów niemiecko-austriackiej kultury prawnej" ${ }^{18}$. Można przypuszczać, iż mogło być to uwarunkowane sytuacją polityczną Włoch ${ }^{19}$. Ponadto należy pamiętać, iż są to pierwsze lata po zjednoczeniu Włoch. Jak podkreśla S. Cassese, w okresie unifikacji brakowało prawa narodowego i nauki narodowego prawa publiczne$\mathrm{go}^{20}$. Jest to o tyle ważne, iż jak można przypuszczać, miało wpływ - co także potwierdza S. Cassese - na kształtowanie się poglądów samego V.E. Orlanda, który, jak wynika z jego bogatego życiorysu, był nie tylko człowiekiem nauki, ale

${ }^{16}$ F. Grassi Orsini, Vittorio Emanuele Orlando: una biografia, [w:] Vittorio Emanuele Orlando: una biografia: mostra documentaria, Soveria Mannelli 2002, s. 3-83.

17 Praca zbiorowa, Vittorio Emanuele Orlando: lo scienziato, il politico e lo statista, Soveria Mannelli 2003.

18 F. Longchamps de Bérier, Wspótczesne..., s. 150.

19 Jak podkreśla M. Żywczyński „[...] rząd włoski musiał szukać zbliżenia do Niemiec. [...] $20 \mathrm{~V} 1882$ r., podpisany został w Wiedniu akt trójprzymierza Niemiec, Austro-Węgier i Włoch. [...] chcąc uniknąć całkowitej izolacji, Włochy musiały w latach osiemdziesiątych szukać oparcia w Niemczech i tylko Niemczech". Za: M. Żywczyński, Włochy nowożytne 1796-1870, Warszawa 1971, s. 185-186.

20 S. Cassese, Auf der gefahrenvollen ..., s. 2. 
i polityki ${ }^{21}$. Jest on uważany za wybitnego luminarza prawa administracyjnego zarówno przez Włochów i nie tylko, jak i przez F. Longchamps de Bériera, kontynuatora jego badań J. Jeżewskiego ${ }^{22}$ czy wcześniej także J.S. Langroda. Ponadto doniosłość badań podkreślał już w 1908 roku Stanisław Posner, stwierdzając: „Orlando to jeden z najbardziej reprezentatywnych prawników współczesnych i profesor w Palermo, później w Rzymie, minister kilkakrotny oświaty i sprawiedliwości, ogłaszać zaczął wielotomowy wykład prawa administracyjnego włoskiego [...]”23. Zaś J.S. Langrod pisał: „W nauce włoskiej na czoło wybija się klasyczny system pióra V.E. Orlanda, prof. Uniwersytetu w Palermo w Primo trattato completo di Diritto amministrativo italiano [...]"24. Choć także do jego dorobku nawiązują inni badacze ${ }^{25}$. Jednakże żeby móc przejść do badań pozwalających ująć koncepcję nauki i samego prawa administracyjnego V.E. Orlanda, należy odnieść się do pojęcia-koncepcji. Jak wskazuje J. Jeżewski, panująca koncepcja prawna to ,pewne poglądy, które występują w życiu prawnym i nauce prawa, a dotyczą generalnego rozwiązania typowych problemów prawnych lub znaczenia głównych pojęć prawnych [...]”26. Koncepcje te „mogą powstać dzięki wpływom z zewnątrz", ale też mogą koncepcje te wytworzyć się w wyniku izolacji - „braku tych wpływów”27. Zatem koncepcja nauki prawa administracyjnego V.E. Orlanda, jak wynika z samego życiorysu, ale także z literatury, do której się on odwołuje, kształtowała się pod silnym wpływem niemieckim, w tym

${ }^{21}$ Urodził się on 19 maja 1860, podjął studia na lokalnym wydziale prawa, po ukończeniu studiów rozpoczął przygotowania do docentury (libera docenza) w zakresie prawa konstytucyjnego. Wykładał w Modenie i Messinie, zaś od 1888 do 1900 roku nauczał prawa administracyjnego w Palermo; za: M. Fotia, Vittorio Emanuele Orlando, [w:] Enciclopedia Italiana, Il Contributo italiano alla storia del Pensiero — Diritto (2012), http://www.treccani.it/ (dostęp: 5.05.2016). Następnie na uniwersytecie w Rzymie wykładał wewnętrzne prawo publiczne i prawo konstytucyjne. Brał czynny udział w życiu politycznym - był deputowanym, także ministrem nauczania publicznego, ministrem sprawiedliwości, a także przewodniczącym rady ministrów. Jednakże dla niniejszych rozważań najistotniejsze będą poglądy Autora na nauki prawne, w tym prawo administracyjne. Za: M.S. Giannini, Vittorio Emanuele Orlando, [w:] Enciclopedia Italiana, Roma 1935.

22 Także A. Błaś i J. Korczak podkreślają doniosłość i znaczenie badań włoskiej administratywistyki dla kształtowania się zrębów wrocławskiej szkoły administratywistycznej. Zob. A. Błaś, $Z$ badań nad administracja publiczna na Wydziale Prawa i Administracji Uniwersytetu Wroclawskiego, [w:] 35-lecie Instytutu Nauk Administracyjnych, red. J. Boć, Wrocław 2007, s. 35-36. Za: J. Korczak, Koncepcja działań niewładczych Profesora Tadeusza Kuty - z dorobku wrocławskiej szkoły administratywistycznej, [w:] Stan i kierunki rozwoju nauk administracyjnych, red. A. Błaś, J. Boć, Wrocław 2014, s. 157.

${ }^{23}$ S. Posner, Prawo włoskie w XIX i XX w., „Gazeta Sądowa Warszawska” 1908, nr 8, s. 466.

24 J.S. Langrod, Nauka prawa administracyjnego w innych językach, [w:] idem, Instytucje prawa administracyjnego. Zarys części ogólnej, reprint, Kraków 2003, s. 132.

25 Zob. A. Peretiatkowicz, Podstawowe pojęcia prawa administracyjnego, Poznań 1947, s. 7; Z. Kmieciak, Zarys teorii postepowania administracyjnego, Warszawa 2014.

26 J. Jeżewski, O porównawczym badaniu koncepcji prawnych „Prawo”, Wrocław 1972, t. 38, s. 63 („Acta Universitatis Wratislaviensis” No 163), s. 63.

27 Ibidem, s. 63. 
niemieckiej szkoły historycznej ${ }^{28}$ i Friedricha Carla von Savigny, co akcentują wspomniani wcześniej F. Longchamps de Bérier i S. Cassese ${ }^{29}$. Przejawiło się to $\mathrm{m}$. in. w podstawowych założeniach jego manifestu dotyczących „czystości nauk prawnych" i nawiązywanie do dorobku prawa rzymskiego i cywilnego. Natomiast w odniesieniu do samego prawa administracyjnego i jego nauki należy określić, jak autor wyodrębnia prawo. Jak pisał F. Longchamps de Bérier: „Dylemat: według przedmiotu czy według sposobu działania — jest znany i od dawna dyskutowany w nauce prawa, gdy idzie o rozgraniczenie podstawowych dziedzin prawa"30. W przypadku drugiego kryterium, jak stwierdza: ,[...] uzyskujemy wtedy dwa pojęcia: pojęcie prawa normującego administrację państwową i pojęcie prawa administracyjnego — o zakresach niekoniecznie pokrywających się"31. Ponadto należy zwrócić uwagę na jeszcze jedno niezwykle cenne dla niniejszych rozważań pytanie badawcze profesora, a mianowicie czy administracji i prawa administracyjnego należy poszukiwać tak samo. Jest to zagadnienie metodologiczne, gdyż autor stwierdza: ,szukajmy osobno określenia administracji państwowej, a osobno określenia prawa administracyjnego. Pierwszego szukajmy w zasadzie „socjologicznie” [...] a drugiego — „prawniczo”32. Tak więc w dalszej części w oparciu o rozważania F. Longchamps de Bériera podjęta zostanie próba m. in. wyodrębnienia przedmiotu oraz celu prawa administracyjnego i nauki administracji, a tym samym próba uchwycenia czy też wyodrębnienia cech koncepcji prawa administracyjnego według V.E. Orlando.

\section{Rekonstrukcja prawa publicznego - manifest}

Rozważania na temat koncepcji nauki prawa administracyjnego według V.E. Orlando należy rozpocząć od tego, co również było podnoszone zarówno przez samego administratywistę, jak i komentatorów jego twórczości, czyli poczucia swoistego nieładu, zdaje się, także metodologicznego, ówczesnej nauki prawa publicznego. Sam autor pisze o „konfuzji kryteriów” (confusione dei criteri sistematici) występującej wówczas w tym obszarze ${ }^{33}$. Problem ten był podnoszony w Principi di diritto amministrativo z 1890, ale także w wydanej w 1889 roku pracy Principi di diritto costituzionale. Jednakże swoistego rodzaju manifestem jego poglądów był tekst opublikowany na łamach „Archivio Giuridico” w 1889

28 A. Sandulli, Santi Romano and the Perception of the Public Law Complexity, „Italian Journal of Public Law" 2009, nr 1, s. 2.

29 S. Cassese, Auf der gefahrenvollen..., s. 8.

${ }^{30}$ F. Longchamps de Bérier, $W$ sprawie.., s. 20.

31 Ibidem.

32 Ibidem, s. 21.

33 V.E. Orlando, Principi di diritto amministrativo, Firenze 1915, s. 1. 
roku ${ }^{34}$. Sam manifest $\mathrm{w}$ doktrynie włoskiej był przedmiotem dyskusji i badań, w tym m.in. podejmowanych przez S. Cassesego, do którego poglądów także warto się odwoływać. Również M.S. Giannini (1915-2000) pisał o programie metodologicznym V.E. Orlando ${ }^{35}$, stwierdzając, iż prawny charakter proponowanych przez niego zmian przejawiał się w postulowaniu (w nawiązaniu do prawa prywatnego) traktowania prawa publicznego jako „systemu zasad prawnych systematycznie skoordynowanych"36, co także podkreśla wspomniany powyżej S. Cassese ${ }^{37}$. Jednocześnie, co także wskazują obydwaj komentatorzy manifestu, V.E. Orlando nakazuje, można powiedzieć, swoistego rodzaju „,czystość” nauk prawniczych, w tym prawa publicznego. Obrazują to słowa przywołane przez S. Cassese'a: „uprawiający prawo publiczne są zbyt filozofami, zbyt politykami, zbyt historykami, zbyt socjologami i zbyt mało prawnikami, podczas gdy w szczególności muszą być właśnie prawnikami”38. Podkreślał to M.S. Giannini, ale i G. Zanobini (1890-1964); pisał on, iż szkoła zapoczątkowana przez V.E. Orlando zainicjowała i rozwijała metodę prawniczą w każdym obszarze prawa publicznego, także prawa administracyjnego ${ }^{39}$, jednocześnie podkreślając przy tym wpływ doktryny niemieckiej nie tylko na omawianego autora, ale na całą ówczesną włoską administratywistykę ${ }^{40}$. Także współcześnie A. Sandulli podkreśla wpływ na kształtowanie się poglądów Orlanda takich niemieckich pisarzy, jak m.in. cywilista A. Brinz czy G.F. Puchta ${ }^{41}$; ponadto także wskazać należy G. Jellinka, którego dzieła tłumaczył na włoski. Wracając do samego manifestu, należy odnotować, iż był to także początek tzw. nowej szkoły włoskiego prawa publicznego ${ }^{42}$. Jak sam V.E. Orlando podkreśla, wewnętrzne prawo publiczne, prawo konstytucyjne i prawo administracyjne wymagają krytycznej rewizji, która niejako przywróci im prawdziwą naturę nauk prawnych ${ }^{43}$. Jednocześnie autor stawia pytanie o sposób osiągnięcia tak wyznaczonego celu, odnosząc się do zawartej w tytule swojego manifestu techniki. Każda nauka ma swoją szczególną technikę, i, jak pisze, wskazujemy tym wyrażeniem wszystkie procedury logiczne, metodyczne, któ-

34 Choć jako materiał niepublikowany były poglądy te, jak wskazuje M.S. Giannini, głoszone przez V.E. Orlanda już na Uniwersytecie w Modenie w roku 1885 i Messynie w 1886 roku. Por. M.S. Giannini, Profili storici.., s. 239; F. Grassi Orsini, op. cit., s. 8.

35 M.S. Giannini, Profili storici..., s. 240.

36 Ibidem.

37 S. Cassese, Il diritto..., s. 514.

38 Ibidem, s. 514.

39 G. Zanobini, Corso di diritto amministrativo, t. 1. Parte generale, Milano 1958, s. 49.

40 Ibidem, s. 50.

41 A. Sandulli, Costruire..., s. 71.

42 L. Casini, S. Cassese, G. Neapoltano, The new Italian public law scholarship, „International Journal of Constitutional Law", 2009, t. 9, nr 2, s. 301-309.

43 V.E. Orlando, I criteri tecnici per la ricostruzione giuridica del diritto pubblico, „Archivio Giuridico" 1889 , t. 42, s. 2. 
re są swoiste i które służą osiągnięciu jej celów własnych ${ }^{44}$. Odwołując się do Iheringa, podkreśla niedoskonałość techniki prawa ${ }^{45}$, jednocześnie podkreślając doniosłość i znaczenie prawa rzymskiego. Ponadto także podnosi kwestię określenia, czym jest praktyka i teoria w obszarze metody prawnej, także w kontekście ich wzajemnej harmonii ${ }^{46}$. Analizując porównawczo korzenie prawa administracyjnego i nauki o nim wskazuje (tak jak m. in. M.S. Giannini ${ }^{47}$ ) Francję, choć jak pisze F. Longchamps de Bérier, przywołując pracę G.D. Romagnosi ${ }^{48}$ z 1814, „[...] biograficznie pierwszeństwo — jak się okaże bezsporne — przypadłoby książce włoskiej"49 . Sam V.E. Orlando odwołuje się do badań i licznych dzieł francuskich, które tworzyli m. in. G.M. Dufour (1811-1868), Louis-Antoine Macarel (1790-1851) czy A. Chauveau (1802-1868). Jednocześnie wskazuje na negowanie w myśli francuskiej kryteriów systematyzacji, w przeciwieństwie do ojczyzny systemu - Niemiec; w tym miejscu przywołuje, ale i analizuje poglądy m.in. R. von Mohla (1799-1875), J.C. Bluntschliego (1808-1881), P. Labanda (1838-1918) czy L. von Steina (1814-1890) ${ }^{50}$. Autor zwraca uwagę na wpływ w tych pracach podejścia filozoficznego, wobec którego także wysuwa zarzuty ${ }^{51}$. Zatem jeśli idzie o manifest, zasadniczy postulat „odnowy” prawa publicznego, w tym prawa administracyjnego i jego nauki, dotyczy przywrócenia, jak sam pisze, ,prawniczości tym naukom”. Poglądy te są widoczne także w innych pracach V.E. Orlanda. Należy zaznaczyć, iż wydanie Principi di diritto amministrativo

\section{Ibidem, s. 2.}

45 Problem ten w polskiej nauce prawa administracyjnego podnosił J.S. Langrod. Jak pisze autor: „Geneza, rozwój i cele prawa administracyjnego tłumaczą nam dostatecznie same przez się — właściwości jego techniki prawnej, a wśród nich przede wszystkim trudność operowania na tym terenie reglamentacją w ogóle, a jednolitymi dziełami kodyfikacyjnymi w szczególności. [...] W prawie administracyjnym panuje wszechwładna prymitywna metoda operowania oderwanymi, okolicznościowymi ustawami [...], obejmującymi reguły różnego rodzaju i różnej treści, z których powiązanie z pewnymi działami administrowania albo z pewnymi teoretycznymi instytucjami, względnie zespołami sytuacyjnymi jest często zewnętrzne. W konsekwencji — aby ustalić ramy prawne dla pewnej materii, trzeba czerpać z wielu ustaw i rozporządzeń, a nawet sięgać do reguł formalnie nieadministracyjnych (np. zwłaszcza karnych)". J.S. Langrod, Właściwości techniki prawa administracyjnego, [w:] idem, Instytucje..., s. 372-398.

46 V.E. Orlando, I criteri..., s. 4-5.

47 M.S. Giannini, Corso di diritto amministrativo, Milano 1965, s. 35. Choć także podkreśla, iż pierwszym opracowaniem prawa administracyjnego było dzieło G.D. Romagnosi.

48 Należy podkreślić, iż także sam V.E. Orlando we wstępie do wydania Principi di diritto amministrativo z roku 1952, przedstawiając rozwój historyczny prawa administracyjnego we Włoszech od 1890 do 1950, zwraca uwagę na doskonałość dwóch prac: właśnie G.D. Romagnosi i neapolitańczyka Manna, który podkreślał rolę państwa w dbaniu o zachowanie prawa. V.E. Orlando, Principi di diritto amministrativo..., s. 27.

49 F. Longchamps de Bérier, Wspótczesne..., s. 15; M. Gromadzka-Grzegorzewska, Narodziny polskich nauk administracyjnych, Warszawa 1985, s. 24. Autorka pisze, iż praca G.D. Romagnosi była pierwszą systematyczną pracą z zakresu teorii prawa administracyjnego.

50 V.E. Orlando, I criteri..., s. 6.

51 Ibidem, s. 7. 
z roku 1952 zostało opatrzone wstępem Rozwój historyczny prawa administracyjnego we Wtoszech pomiędzy rokiem 1890 a 1950. Już na jego początku zostaje podkreślone, iż wszyscy są zgodni, że prawo administracyjne jest gałęzią nowoczesnego prawoznawstwa. Badając genezę tego prawa, należy zwrócić uwagę na podwójne znaczenie użycia, jak pisze, słowa „prawo”. Z jednej strony może być ono pojmowane jako układ (ordinamento) i jako normy, z drugiej zaś jako zespół badań (prawoznawstwo i doktryna), które tworzą system, częściowo autonomiczny w obszarze nauk prawnych; to wówczas będzie według autora prawo administracyjne pojmowane jako nauka ${ }^{52}$.

\section{Kryteria wyodrębnienia prawa administracyjnego}

Należy już na wstępie zaznaczyć, iż V.E. Orlando, badając prawo administracyjne i jego naukę, odgranicza je od nauki administracji. Autor czynni to m.in. poprzez wskazanie kryteriów, które, jak pisze, można odnaleźć w definicjach prawa administracyjnego - jest to po pierwsze odniesienie się i komentowanie ustaw (praw) administracyjnych (leggi amministrative) ${ }^{53}$. Kryterium to łączy się z innymi. Jednocześnie badacz wskazuje, że twierdzenie, jakoby nauka prawa (scienza del diritto) była nauką ustaw, prawa (scienza delle leggi) - badaniem ustawodawstwa, pozostaje zawsze prawdziwe. Ponadto, zwracając uwagę na odrębność prawa publicznego i prywatnego, stwierdza, iż komentowanie artykułów praw-ustaw gminnych i prowincjonalnych nie jest czymś innym niż komentowanie artykułu kodeksu handlowego ${ }^{54}$. Drugie kryterium, które według autora było dominujące w szkołach włoskiej oraz francuskiej, dotyczy twierdzenia, iż elementem definicji prawa administracyjnego jest władza wykonawcza (potere esecutivo) ${ }^{55}$. Prawo administracyjne byłoby niejako teorią aktów władzy wykonawczej. Jednocześnie zwraca on uwagę, iż takie ujęcie będzie skutkowało trudnością definiowania i wszelkimi niejasnościami narosłymi wokół teorii podziału władzy ${ }^{56}$. Ponadto także przyjęcie takiego kryterium może nieść problem rozgraniczenia prawa administracyjnego od prawa konstytucyjnego. Omawiając kolejne kryteria, nawiązuje do francuskiej koncepcji służby publicznej. Na kanwie tych rozważań stwierdza, że kryterium łączące tę koncepcję z ideą stosunków między obywatelami i państwem jest o tyle zawodne, iż jest wspólne dla prawa administracyjnego, ale i prawa konstytucyjnego, zwłaszcza w zakresie teorii wolności ${ }^{57}$. Na koniec

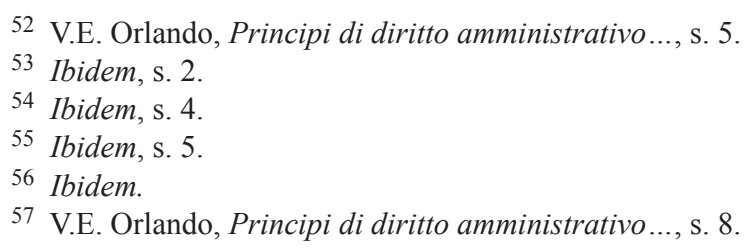


odwołuje się także do swoistego pojmowania w doktrynie amerykańskiej niejako podziału dwóch elementów: publicznej administracji i prawa administracyjnego.

\section{Ujęcie prawa administracyjnego}

\subsection{Prawo administracyjne a prawo konstytucyjne}

Badając prawo administracyjne i naukę o nim, V.E. Orlando przede wszystkim podkreśla podział na prawo prywatne i publiczne. Ponadto wskazuje na prawo państwa (diritto dello Stato) w sensie szerokim odpowiadające prawu publicznemu — ściślej — wewnętrznemu prawu publicznemu (diritto pubblico interno) ${ }^{58}$. Państwo, jako organizm prawny, ma swój własny porządek, składa się z różnych organów-stosunków między nimi, organy te realizują określone zadania. Zaś razem zasady prawne, które temu porządkowi, tym stosunkom i tym zadaniom przewodniczą, mogą tworzyć naukę autonomiczną — prawo konstytucyjne ${ }^{59}$. Dalej, jak pisze, państwo już zorganizowane, stworzone musi koniecznie mieć cele do realizacji. Musi także podejmować własne działania środkami różnej natury. Zatem nauka nasza, pisze Orlando, mając na myśli prawo administracyjne, jest to system tych zasad prawnych, które regulują działalność państwa dla osiągnięcia swoich celów ${ }^{60}$. Zarówno V.E. Orlando, ale także wielu innych administratywistów włoskich, jak np. C.F. Ferraris ${ }^{61}$, wyróżnia działalność (działania) administracji o charakterze społecznym i prawnym ${ }^{62}$. Wyodrębnienie to dla niektórych autorów włoskich (m.in. C.F. Ferrarisa) stanowi podstawę wyodrębnienia prawa administracyjnego od nauki administracji, choć także w tym miejscu V.E. Orlando podnosi pewne wątpliwości.

Badając cele główne prawa administracyjnego, w tym badania prawne działalności państwa, zwraca uwagę, iż bez precyzyjnego określenia różnych zagadnień-pojęć, które składają się na działalność państwa, nie jest możliwe osiągnięcie

58 Ibidem, s. 12.

59 Ibidem, s. 13.

${ }^{60}$ Ibidem, s. $14-15$.

61 C.F. Ferraris, La statistica e la scienza dell'amministrazione nelle facoltà giuridiche, „Giornale degli Economisti” 1877, t. 5, nr 4, s. 225-252.

${ }^{62} \mathrm{~W}$ polskiej doktrynie problem zarówno w aspekcie teoretycznym, ale i praktycznym działań administracji podejmuje A. Błaś w m.in. idem, Pojęcie działań złożonych administracji. Studium z metodologii badań nad działaniami administracji, Wrocław 1977 [maszynopis]; idem, Proces administrowania jako zorganizowany układ działań administracji publicznej, „Prawo” XXXVI, Wrocław 1972, s. 83-90 („Acta Universitatis Wratislaviensis”); idem, Prawne aspekty działań złożonych administracji państwowej, „Przegląd Prawa i Administracji” VI, Wrocław 1975, s. 101-110 („Acta Universitatis Wratislaviensis"); idem, Z problematyki badań nad działaniami administracji państwowej, „Prawo” CXLIII, Wrocław 1985, s. 19-26, („Acta Universitatis Wratislaviensis”). 
ścisłych i naukowych wytycznych dla ujęcia czy też - uchwycenia, prawa administracyjnego ${ }^{63}$. Ponadto człowiek społeczny (uomo socievole) może realizować swoje potrzeby jedynie współżyjąc w społeczeństwie. Tworzenie warunków tego współżycia w dużej mierze jest zdeterminowane prawem ${ }^{64}$. Tym samym podstawowym celem, jaki wskazuje Orlando dla państwa, jest ochrona prawa stosunków między członkami społeczeństwa oraz zapewnienie rządów prawa.

\subsection{Prawo administracyjne a działalność społeczna i prawna}

Wyodrębnienie, na które zwrócono uwagę w poprzednim punkcie, nasuwa pytanie o to, co autor rozumie pod pojęciem działań działalności (attività) społecznej państwa? Jak wyjaśnia V.E. Orlando, państwo podejmuje także środki dla wspierania i polepszenia rolnictwa czy przemysłu, otwiera $\mathrm{i}$ wspiera nowe rynki oraz handel, buduje i utrzymuje drogi, tworzy i reguluje banki, utrzymuje szkoły itp. ${ }^{65}$. Jest to więc realizacja celów koniecznych, które nie mogą być realizowane bez pomocy państwa. Zatem z jednej strony mamy działalność (czy szerzej - cele) dotyczącą wymiaru prawnego, jak ochrona prawa czy tworzenie porządku-ładu prawnego państwa. Zaś z drugiej — działalność państwa, poprzez którą państwo ingeruje w stosunki społeczne, ale już nie, jak stwierdza V.E. Orlando, dla regulacji prawnej (regolare giuridicamente), ale dla wspierania dobrobytu (benessere), bogactwa (ricchezza) czy kultury. I właśnie tę działalność autor nazywa „społeczną" (attività sociale) ${ }^{66}$. Na koniec V.E. Orlando stawia pytanie, w jaki sposób, jakimi kryteriami badać działania tak wyodrębnione z punktu widzenia prawa administracyjnego jako nauki o działaniach (działalności) państwa. I w tym miejscu autor podnosi kwestie rozróżnienia badań prawa administracyjnego i nauki administracji (scienza dell' amministrazione) ${ }^{67}$. Ponownie jednakże podkreśla doniosłość posługiwania się metodą prawniczą tym razem w badaniach nad materią dotyczącą publicznej administracji ${ }^{68}$. Zwraca on uwagę na konieczność rozróżnienia badań prawniczych od nieprawniczych, czyli badanie tychże działań pod różnymi aspektami, jak wskazuje, np. politycznym, technicznym czy ekonomicznym ${ }^{69}$. Początkowo nauka administracji miała opisywać ogólną naturę administracji publicznej i zbierać (raccolta) racjonalne naczelne zasady, zaś prawo administracyjne, stwierdza, także miało zajmować się zasadami; ale są to zasady wynikłe - przekładane w prawie (principii tradotti in leggi) — więc

63 V.E. Orlando, Principi di diritto amministrativo..., s. 18.

64 Ibidem, s. $18-19$.

65 Ibidem.

66 Ibidem, s. 21-22.

67 Ibidem, s. 22.

68 Ibidem.

69 Ibidem, s. 23. 
z jednej strony, pisze V.E. Orlando, filozofia prawa administracyjnego, z drugiej - prawo-ustawodawstwo $^{70}$. Jednocześnie ukazuje różne stanowiska wypracowane w doktrynie włoskiej na temat stosunków prawa administracyjnego i nauki administracji, odwołując się przy tym do takich luminarzy włoskiej administratywistyki, jak m.in. L. Meucci czy E. Persico ${ }^{71}$. Ponadto jego badania, które przedstawiają spojrzenie doktryny niemieckiej na omówiony problem, w tym w szczególności analiza poglądów Loninga, Gerbera, Mayera czy w końcu Lorenza von Steina, świadczą o ogromnej wiedzy, ale także naukowej świadomości V.E. Orlanda zarówno administratywistyki niemieckiej, jak i jej odmienności względem jego rodzimej doktryny ${ }^{72}$.

Wywody i swoistego rodzaju analiza pozwalają na dokonanie podziału systematyki ujęcia badanej przez niego nauki. Naturalny podział, jak stwierdza, ogromnego materiału, który zawiera się w tejże nauce można ująć w trzech wielkich częściach: organizacja administracji, działalność administracji oraz obrona praw jednostek wobec administracji ${ }^{73}$.

\subsection{Obszar badawczy prawa administracyjnego i nauki o nim}

Sformułowane przez V.E. Orlando trzy obszary badawcze odpowiadają także konstrukcji jego pracy Principi di diritto amministrativo. Mimo iż składa się ona z ośmiu ksiąg, to podejmowana w niej tematyka odpowiada właśnie wcześniej wspomnianym obszarom. Pierwsza księga, do której w dużej mierze odwoływały się niniejsze rozważania, dotyczyła nauki. W drugiej autor zajmuje się organizacją z wyodrębnieniem na urzędy administracji centralnej, stosunki pomiędzy urzędnikami (impiegati) i państwem oraz organizacji administracji lokalnej. W pierwszym podpunkcie podejmuje problematykę dotyczącą ujęcia i definiowania pojęć takich, jak urząd publiczny, organ, funkcjonariusz także w kontekście celów publicznych. Ponadto autor, jak czynił to już R. von Mohl, podejmuje problem organizacji urzędów ${ }^{74}$, hierarchii administracyjnej. Obszernie także traktuje on o poszczególnych instytucjach administracji centralnej, jak: instytucji ministra, Rady Państwa, Trybunale Obrachunkowym (Corte dei conti), organach doradczych ministrów (dla przykładu wskazać można, jak pisze, działającą przy ministrze spraw zagranicznych Radę Sporów Dyplomatycznych, ustanowioną w Królestwie Sardynii w 1857 roku $^{75}$. Traktując zaś o urzędnikach, zwraca uwa-

70 Ibidem, s. 24.

71 Ibidem, s. 27.

72 Szerzej: także V.E. Orlando, Principi di diritto costituzionale, Firenze 1889, s. 7 n.

73 V.E. Orlando, Principi di diritto amministrativo..., s. 45; S. Cassese, Il diritto..., s. 267.

74 R. von Mohl, Encyklopedia umiejętności politycznych, przeł. A. Białecki (pierwsze wydanie z 1859 roku), reprint Warszawa 2003, s. 534-539.

75 V.E. Orlando, Principi di diritto amministrativo..., s. 105. 
gę m.in. na ich odwoływalność, odpowiedzialność cz też obowiązki. Obszerne rozważania obejmują tematykę związaną z administracją lokalną. Są to zarówno rozważania teoretyczne dotyczące np. rozumienia jednostki autarkicznej (enti autarchici), podziału administracyjnego terytorium, ale także podejmuje problemy podstawowe, jak wolność, autonomia, i decentralizacja ${ }^{76}$. Następnie zaś traktuje obszerniej o administracji gminnej, prowincjonalnej i regionie ${ }^{77}$. Księga szósta otwiera drugi obszar badań wskazany przez V.E. Orlando, a mianowicie działania administracyjne ${ }^{78}$. Zasadniczy podział, jaki przyjmuje autor w zakresie działalności administracji to podział na działalność prawniczą (w tym miejscu podnosi zagadnienie aktu administracyjnego, wyodrębnienia aktów związanych i dyskrecjonalnych, klasyfikacji aktów a także środków policji) i działalność społeczną ${ }^{79}$ (attività sociale) $^{80}$. Zaś ostatnie dwie księgi mieszczą się w trzecim obszarze zainteresowań prawa administracyjnego i w przypadku dzieła V.E. Orlanda obejmują obronę wobec działań administracji ${ }^{81}$ i obowiązki państwa ${ }^{82}$. W tym miejscu autor podejmuje problem praw podmiotowych, w tym praw podmiotowych pełnych, interesów prawnych uwarunkowanych, interesów prawnych chronionych okazjonalnie $^{83}$. Ponadto przedstawione zostają także instytucje procesowe umożliwiające ochronę tychże praw, jak skarga, rekurs administracyjny i rekurs sądowy ${ }^{84}$.

76 Ibidem, s. 187.

${ }^{77}$ Należy odnotować, iż podpunkt dotyczący regionu nie występował w wydaniach wcześniejszych Principi di diritto amministrativo np. z roku 1915, gdyż, jak sam autor zauważa w wydaniu z roku 1952, to Konstytucja Włoska stworzyła nową terytorialną jednostkę publiczną. V.E. Orlando, Principi di diritto amministrativo..., s. 286.

78 Ibidem, s. 299-400.

79 Jednakże, jak sam autor podnosi, także i działania społeczne mają niejako wymiar, stronę prawną. Autor przytacza przykład szkolnictwa podstawowego, które łączy się jednocześnie z ograniczeniem wolności osobowej rodziców. Por. ibidem, s. 382-383. Zaś na tle rozważań o działaniach społecznych zwraca uwagę, iż wśród stosunków społecznych można wyodrębnić stosunki fizyczne, gospodarcze i duchowe. Por. ibidem, s. 384.

80 Jak wskazują R. Chieppa, V. Lopilato, V.E. Orlando we wprowadzeniu do Primo Trattato completo di diritto amministrativo wyodrębnia w obszarze działalności administracyjnej trzy rodzaje działalności: prawną, społeczną oraz działalność majątkową (attività patrimoniale). Działalność społeczna, jak piszą autorzy, są to działania bezpośrednio wspierające cywilizację ludności w jej różnych przejawach — dobrobytu fizycznego, gospodarczego i intelektualnego. Działalność społeczna, jak podają autorzy, różnicuje się na działania prawne obejmujące obronę, porządek publiczny i sądownictwo i działalność majątkową (attività patrimoniale). Za: R. Chieppa, V. Lopilato, Studi di diritto amministrativo, Milano 2007, s. 701.

${ }^{81}$ Należy zaznaczyć, iż V.E. Orlando podnosząc problem stosunków między jednostką a państwem stwierdził, iż jest to przedmiot dwóch nauk — zarówno prawa konstytucyjnego, jak i prawa administracyjnego. Prawo konstytucyjne rozważa te stosunki z punktu widzenia stwierdzenia prawa jednostki i odnosi się do aspektu teoretycznego wolności (teorica della liberta), zaś prawo administracyjne rozważa przeciwnie punkt widzenia obowiązku, który spoczywa na władzy, ochrony porządku i bezpieczeństwa publicznego wobec przypadków ich naruszeń. V.E. Orlando, Principi di diritto amministrativo..., s. 323.

82 Na ten temat zob. A. Sandulli, Costruire..., s. 80.

83 Por. F. Longchamps de Bérier, Współczesne..., s. 172-173.

84 V.E. Orlando, Principi di diritto amministrativo ..., s. 401-447.

Prawo 320, 2016

(C) for this edition by CNS 


\section{Wnioski}

Reasumując, należy podkreślić, iż praca badawcza, jaką prowadził V.E. Orlando zaowocowała powstaniem włoskiej szkoły prawa publicznego ${ }^{85}$. Swoje poglądy przedstawiał on nie tylko podczas wykładów i w podręcznikach, ale także na łamach założonego w 1891 roku periodyka „Archivio di diritto pubblico" 86 . Głównym postulatem manifestu Orlanda było, jak podkreślają zarówno M.S. Giannini i E. Casetta, jak i S. Cassese, stosowanie techniki opracowanej przez naukę prawa rzymskiego. Oznaczało to, jak pisze M.S. Giannini, ponowne sięganie do techniki pandektystów (tecnica della pandettistica ${ }^{87}$. Warto odwołać się także do badań F. Longchamps de Bériera, który wyraźnie podkreśla, iż szkoła pandektystów była „,decydującym wszakże czynnikiem, który ukształtował całą szkołę niemiecko-austriacką prawa publicznego, [...] która w połowie zeszłego stulecia była panującą szkołą myśli prawnej w krajach niemieckich" ${ }^{88}$. Podkreśla także, że „Szkoła Orlanda i jego uczniów połączyła w tym przedmiocie dwa wątki myśli europejskiej: francuski i niemiecko-austriacki, i niektóre ich cechy doprowadziła, w tym połączeniu do wręcz mistrzowskiej doskonałości i harmonii. [...] Z nastawieniem realistycznym i troską o praktyczną przydatność, które znamionowały francuską myśl prawną Restauracji, nowe wzory niemieckie, predylekcje do systemu [...] dały tu razem pewną swoistą i niezrównaną całość" 89 .

Zatem szkoła zapoczątkowana przez V.E. Orlando, jak stwierdza E. Casetta, postulowała rekonstrukcję prawa publicznego przez metodę prawniczą, ale także ograniczenie wpływu m.in. socjologii, ekonomii, polityki w naukach prawniczych, w tym także nauce prawa administracyjnego ${ }^{90}$. Również koncepcja prawa publicznego ${ }^{91}$, w tym administracyjnego i nauki o nim, autorstwa V.E. Orlando, która dała podwaliny pod tę szkołę, będzie zawierać w sobie te elementy. W szczególności jej prawniczy charakter, jak sam autor podkreślał, musi determinować zarówno treść, jak i jej metodę 92 .

Należy stwierdzić, iż V.E. Orlando nie tylko był, ale nadal pozostaje fundamentem włoskiej administratywistyki. Zapoczątkowana przez niego włoska szkoła prawa publicznego była kontynuowana i modyfikowana przez jego uczniów,

85 Szerzej na temat włoskiej szkoły prawa publicznego (scuola giuridica italiana di diritto pubblico): S. Casses, Il diritto...; E. Casetta, Manuale di diritto amministrativo, Milano 2011, s. 18.

${ }^{86}$ A. Sandulli, Costruire..., s. 288.

${ }^{87}$ M.S. Giannini, Profili storici..., s. 242; G. Melis, La storia del diritto amministrativo, [w:] S. Cassese, Trattato di diritto amministrativo, Milano 2003, s. 110.

${ }^{88}$ F. Longchamps de Bérier, Wspótczesne..., s. 19.

89 Ibidem, s. 151.

90 E. Casetta, op. cit., s. 18.

91 Należy zaznaczyć, iż o prawie publicznym ogólnym, w tym o jego systemie i klasyfikacji, nauce prawa publicznego autor traktuje w: V.E. Orlando, Diritto pubblico generale: scritti varii (1881-1940), Milano 1940.

92 Ibidem, s. 45.

Prawo 320, 2016

(C) for this edition by CNS 
którzy także tworzyli i tworzą administratywistykę włoską. Powstałe pod jego kierunkiem wielotomowe dzieło Primo trattato completo di diritto amministrativo italiano, w którym znalazły się opracowania monograficzne jego uczniów i nie tylko, jak m.in. O. Ranellettiego (1868-1956), F. Cammea (1872-1939) czy S. Romana (1875-1947) do dziś pozostają zaliczane do kanonu europejskiej administratywistyki ${ }^{33}$.

\section{The notion of administrative law and science of administrative law in the concept of V.E. Orlando}

Summary

The purpose of this article is to demonstrate the influence of German writers, first of all the pandectists, on the thought of V.E. Orlando and the role they played. Orlando was the founder and constructor of Italian public law scholarship. The paper is based on the research of F. Longchamps de Bérier, but also M.S. Giannini, A. Sandulli and S. Cassese. The article describes three issuesproblems. The first concerns the reasons for and conditions of the study of V.E. Orlando, particularly historical conditions. The second focuses on the principal theses of his manifesto. The last question is dedicated to one of the major handbooks of administrative law by this author - Principi di diritto amministrativo. The results confirm the opinion of F. Longchamps de Bérier and S. Casses, that the conception of V.E. Orlando was the determinant of the pandectists thought.

Keywords: administrative law, V.E. Orlando, Longchamps de Bérier, pandectists.

\section{Bibliografia}

Błaś A., Pojęcie działań złożonych administracji. Studium z metodologii badań nad działaniami administracji, maszynopis, Wrocław 1977.

Błaś A., Prawne aspekty działań złożonych administracji państwowej, „Przegląd Prawa i Administracji” 6, Wrocław 1975 („Acta Universitatis Wratislaviensis”).

Błaś A., Proces administrowania jako zorganizowany układ działań administracji publicznej, „Prawo” XXXVI, Wrocław 1972, („Acta Univesitatis Wratislaviensis”).

Błaś A., Studia z nauki prawa administracyjnego i nauki administracji, Wrocław 1998.

Błaś A., Z badań nad administracja publiczna na Wydziale Prawa i Administracji Uniwersytetu Wrocławskiego, [w:] 35-lecie Instytutu Nauk Administracyjnych, red. J. Boć, Wrocław 2007.

Błaś A., Z problematyki badań nad działaniami administracji państwowej, „Prawo” CXLIII, Wrocław 1985 („Acta Universitatis Wratislaviensis”).

Casetta E., Manuale di diritto amministrativo, Milano 2011

Casini L., Cassese S., Neapoltano G., The new Italian public law scholarship, „International Journal of Constitutional Law" 2009, t. 9, z. 2.

93 G. Melis, op. cit, s. 112; S. Cassese, Il diritto..., s. 267; A. Sanduli, Santi Romano..., s. 4. 
Cassese S., Auf der gefahrenvollen Strasse des öffentlichen Rechts. La rivoluzione scientifica di Vittorio Emanuele Orlando, Berlin 2010, http://www.irpa.eu/wp-content/uploads/2011/10/ auf-der-gefahrenvollen-Strasse-des-offentlichen-rechts.pdf.

Cassese S., Il diritto amministrativo: storia e prospettive, Milano 2010.

Chieppa R., Lopilato V., Studi di diritto amministrativo, Milano 2007.

Cianferotti G., Il pensiero di V.E. Orlando e la giuspubblicistica italiana fra ottocento e novecento, „The American Historical Review” 1982, t. 87, nr 1.

Ferraris C.F., La statistica e la scienza dell'amministrazione nelle facoltà giuridiche, „Giornale degli Economisti" 1877, t. 5, nr 4.

Fotia M., Vittorio Emanuele Orlando in Il Contributo italiano alla storia del Pensiero-Diritto, Roma 2012.

Giannini A., Vittorio Emanuele Orlando, [w:] Enciclopedia Italiana, Roma 1935.

Giannini M.S., Corso di diritto amministrativo, Milano 1965.

Giannini M.S., Profili storici della scienza del diritto amministrativo, „Quaderni Fiorentini” 1973, nr 2.

Grassi Orsini F., Vittorio Emanuele Orlando. Una biografia, [w:] Vittorio Emanuele Orlando. Una biografia. Mostra documentaria, Rubbettino 2002.

Gromadzka-Grzegorzewska M., Narodziny polskich nauk administracyjnych, Warszawa 1985.

Jeżewski J., Administracja pod rządem prawa cywilnego. Z badań prawnoporównawczych nauki prawa administracyjnego, Wrocław 1974.

Jeżewski J., Franciszek Longchamps de Bérier (1912-1969), [w:] Pamięci zmartych Profesorów i Docentów Wydziału Prawa, Administracji i Ekonomii Uniwersytetu Wrocławskiego 19452010, red. L. Lehmann, M. Maciejewski, Wrocław 2010.

Jeżewski J., Francuska koncepcja poddania administracji publicznej prawu powszechnemu, „Prawo” XXX, Wrocław 1972, („Acta Universitatis Wratislaviensis” No 169).

Jeżewski J., O porównawczym badaniu koncepcji prawnych, „Prawo” XXXVIII, Wrocław 1972, („Acta Universitatis Wratislaviensis” No 163).

Kmieciak Z., Zarys teorii postępowania administracyjnego, Warszawa 2014.

Konstytucje Rzeczypospolitej oraz komentarz do Konstytucji RP z 1997 r., red. J. Boć, Wrocław 1998.

Korczak J., Koncepcja działań niewładczych Profesora Tadeusza Kuty - z dorobku wrocławskiej szkoły administratywistycznej, [w:] Stan i kierunki rozwoju nauk administracyjnych, red. A. Błaś, J. Boć, Wrocław 2014.

Korczak J., Konstytucyjne podstawy struktury i funkcji samorzadu terytorialnego, [w:] Konstytucyjne podstawy funkcjonowania administracji publicznej, Warszawa 2012, („,System Prawa Administracyjnego", red. R. Hauser, Z. Niewiadomski, A. Wróbel, t. 12).

Korczak J., Pozyskiwanie i umacnianie zaufania do władz publicznych przez współadministrowanie, [w:] Sprawiedliwość i zaufania do władz publicznych $w$ prawie administracyjnym, red. M. Stahl, M. Kasiński, K. Wlaźlak, Warszawa 2015.

Langrod J.S., Nauka prawa administracyjnego $w$ innych językach, [w:] idem, Instytucje prawa administracyjnego. Zarys części ogólnej, reprint, Kraków 2003.

La scienza del diritto amministrativo nella seconda meta del XX secolo, red. L. Torchia, E. Chiti, A. Sandulli, Napoli 2008.

Longchamps de Bérier F., O administracji publicznej (Problem poznawczy), [w:] Księga pamiatkowa ku czci prof. dra Witolda Świdy, red., J. Fiema, W. Gutekunst, S. Hubert, Warszawa 1969.

Longchamps de Bérier F., Problemy pogranicza prawa administracyjnego. Wstępne założenia, „Studia Prawnicze” 1967, z. 16.

Longchamps de Bérier F., W sprawie pojęcia administracji państwowej i pojęcia prawa administracyjnego, „Zeszyty Naukowe Uniwersytetu Wrocławskiego im. Bolesława Bieruta” 1958, nr 10. 
Longchamps de Bérier F., Współczesne kierunki w nauce prawa administracyjnego na zachodzie Europy, reprint, Wrocław 2001.

Melis G., La storia del diritto amministrativo, in S. Cassese, Trattato di diritto amministrativo, Milano 2003.

Mohl R. von, Encyklopedia umiejętności politycznych, przeł. A. Białecki, reprint, Warszawa 2003.

Orlando V.E., Diritto pubblico generale: scritti varii (1881-1940), Milano 1940.

Orlando V.E., I criteri tecnici per la ricostruzione giuridica del diritto pubblico, „Archivio Giuridico" 1889 , t. 42.

Orlando V.E., Principi di diritto amministrativo, Firenze 1915.

Orlando V.E., Principi di diritto costituzionale, Firenze 1889.

Peretiatkowicz A., Podstawowe pojęcia prawa administracyjnego, Poznań 1947.

Posner S., Prawo włoskie w XIX i XX w., „Gazeta Sądowa Warszawska”, 1908, nr 8.

Praca zbiorowa, Vittorio Emanuele Orlando: lo scienziato, il politico e lo statista, Rubbettino 2003.

Rameri L., „Principii di Diritto Amministrativo” by Orlando V.E., „Giornale degli Economisti” 1891, t. 3.

Sandulli A., Costruire lo Stato: la scienza del diritto amministrativo in Italia, 1800-1945, Milano 2010.

Sandulli A., Santi Romano and the Perception of the Public Law Complexity, „Italian Journal of Public Law" 2009, nr 1.

Zanobini G., Corso di diritto amministrativo. Parte generale, t. 1, Milano 1958.

Żywczyński M., Włochy nowożytne 1796-1870, Warszawa 1971. 